\title{
IRANIAN WOMEN'S VEILING AS A GENDER PERFORMANCE: SINCE PREMODERN ERA TO THE CURRENT AGE
}

\author{
Leila Khadem Makhsuos Hosseini
}

Independent Researcher, Tehran, Iran

leila.hosseiny60@gmail.com

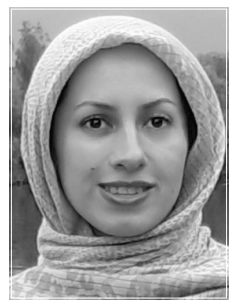

\begin{abstract}
Iranian women's veiling, as one of the major concerns of both women and the state, has been the subject of various studies. The present study in its broad range of investigation covers discussion of Iranian women's hijab since pre-modern Iran to the current age. Meanwhile, it is more than a new historicist reflection on the way discourses construct norms. Here, within the framework of Butler's performative theory, veiling is approached as a gender performance, which constructs and represents the identity of the wearer. The question is how Iranian women's veiling as a gender performance is associated with competing discourses, and how recitations of veiling give them agency. It is hypothesized that women are not simply imposed the norm of veiling by the dominant discourses; rather, as active agents they can change the norms as they perform deviated recitation of norm of veiling. Veiling as a signifier has given different significations in each era, ranging from modesty, backwardness, nationalism, revolutionary, to displaying protest. We address the meanings that different dressing styles represent in three eras of pre-constitutional, post-constitutional, and post- revolutionary in Iran. Homogenized imposed veiling by Islamic authorities in pre-modern Iran, withdrew with secularization of state, was invoked as sign of revolution against the state, re-imposed by the state and ultimately fashioned by women. Thus, veiling in Iran is burdened with more cultural and even political meaning. In each discourse, the performance of veiling style defines women's subjectivity as normal or abject. Women to be identified as viable subject perform the norms of religious or secularized modern discourse. The two produced binary polar, representing two kinds of subjectivities produced a gap between veiled, unveiled women or properly veiled and misveiled women. The imposed, removed and re-imposed hijab has not been the terminal decision of discourses. It is confirmed that today, Iranian women, supplied with education and global media can reflexively consider and fashion their identity. Nowadays, Iranian women's fashion hijab is a deviated recitation of the idealized norm to resist the imposed norm. Fashion hijab as a deviated recitation of originally intended hijab by Islamic state is a threat to the Islamic discourse. Therefore, it is regarded as soft war imposed by Western culture on Iran. It is concluded that there has been a dialectical relationship between veiling performance of subjects as agents and viability of the dominant discourse.
\end{abstract}


Keywords: gender performativity, recitation of norms, Iranian women, veiling, competing discourses, preand post-constitutional and post-revolutionary era

For citation: Khadem Makhsous Hosseini, L. (2021) 'Iranian Women's Veiling as a Gender Performance: Since Premodern Era to the Current Age', Concept: Philosophy, Religion, Culture, 5(1), pp. 110-120. https://doi. org/10.24833/2541-8831-2021-1-17-110-120

\title{
ОТ ПРЕМОДЕРНА ДО НАШИХ ДНЕЙ: ХИДЖАБ ИРАНСКИХ ЖЕНЩИН КАК ПЕРФОРМАТИВ
}

\author{
Хадем Максус Хоссейни Л.
}

Независимый исследователь, Тегеран, Иран

leila.hosseiny60@gmail.com

\begin{abstract}
Аннотация. Статья посвящена вопросу женской мусульманской одежды в Иране, отношениям и нормам, с которыми связана одежда. Настоящее исследование охватывает обсуждение хиджаба, регулирование одеяний государством и самими женщинами, начиная с шахской эпохи (до первой конституции Ирана и после её принятия) и заканчивая современным этапом. Методологически работа опирается на культурологический подход, рассматривающий представления, нормы, отношения и нарративы. В данном случае, в центре внимания исследователя находятся дискурсы, конструирующие предписания и нормы. Взяв на вооружение теоретический аппарат перформативной теории Дж. Батлер, автор рассматривает ношение хиджаба как конкретный гендерный перформатив, который конструирует и репрезентирует личность. Центральный исследовательский вопрос заключается в том, каким образом использование иранскими женщинами одежд, скрывающих тело, взятое как гендерный перформатив, связано с конкурирующими дискурсами в иранском обществе и как следование предписываемой «норме» ношения хиджаба даёт женщинам свободу действий на практике. Предполагается, что картина принуждения женщин слишком проста: на деле ношение хиджаба определено не только доминирующими дискурсами. Скорее, женщины как активные агенты могут изменять эти нормы, следуя обязанности ношения хиджаба, делать это по-своему, отклоняясь от нормы и изменяя её. В разные эпохи хиджабу придавались разные символические значения, начиная от скромности, отсталости, национализма, революционности и заканчивая демонстрацией протеста. Нормативность хиджаба, навязанная исламскими властями в домодерном Иране, исчезла вместе с секуляризацией государства до революции 1979 г., но после вернулась сначала как вызов государству, а потом вновь как навязанный императив - и в конечном счете была адаптирована современными женщинами. Таким образом, хиджаб в Иране нагружен большим культурным и политическим значением, и в каждом дискурсе (религиозном или секуляризованном) сигнализирует либо о субъектности женщины, либо о её маргинальном статусе, разделяет одетых и неодетых в хиджаб, правильно и неправильно носящих это одеяние. Навязанное, упраздненное и вновь навязанное ношение хиджаба в русле различных дискурсов, однако, не столь успешно с точки зрения утверждения тотальной нормы. Данные свидетельствуют: сегодня иранские женщины, имея доступ к образованию и мировым СМИ, могут рефлексировать по поводу собственной идентичности и формировать её. В наши дни практики ношения хиджаба, ориентирующиеся на моду и стиль, представляют собой следование формальному правилу, которое само по себе противостоит навязанной норме. Укладываясь в исламский постулат о закрытом теле, новый модный хиджаб отклоняется от рамок,
\end{abstract}


продиктованных долговременной политикой исламского Ирана, и тем самым, как ни парадоксально, угрожает исламскому дискурсу. Именно поэтому новшества в традиционном одеянии рассматриваются на высоком уровне как скрытая мягкая война, навязанная Ирану западной культурой. Главный вывод таков: между практикой ношения хиджаба женщинами - действующими субъектами и устойчивостью доминирующего дискурса существует диалектическая Связь.

Ключевые слова: гендерный перформатив, следование норме, женщины в Иране, хиджаб, конкурирующие дискурсы, доконституционный период в Иране, Иран после первой конституции, Иран после исламской революции

Для цитирования: Хадем Максус Хоссейни Л. От премодерна до наших дней: хиджаб иранских женщин как перформатив // Концепт: философия, религия, культура. - 2021. - Т. 5, № 1. - C. 110-120. https://doi.org/10.24833/2541-8831-2021-1-17-110-120

\section{Introduction}

$\Delta$ ncient Persian women would cover their bodies with skirts or dresses. The advent of Islam introduced hijab as a proper cultural norm. Safavi dynasty (15011722), as the founder of Shiia trend in Iran glorified the position of religious clericals in effort to establish a religious country and imposed veiling on women. Today, veiling throughout the world represents a Muslim woman; thereby it stands for gender and religious identity.

Here, we investigate the meanings that veiling has represented throughout three different eras in Iran: pre-constitutional, post-constitutional and post-revolutionary eras. We assess how alteration of women's dressing style has been associated with transformation of their cultural identity. The analysis will be mainly based on our understanding of performative theory coined by Judith Butler, a poststructuralist feminist. It is hypothesized that women are not simply imposed the norms; rather, as active agents they can change the norms with deviated recitation of norm of veiling.

Butler believes that to gain identity one is assigned sex as girl or boy. The moment sex is identified, specified properties are ascribed to body and the body is materialized [Butler, 2011: 7]. The subject to maintain her identity needs to perform these norms. On the other hand, the discourse, which has ascribed these norms, needs the subject to perform the norms. "For power to act there must be a sub- ject" [Butler, 1997: 203]. If conditions of power are to persist, they must be reiterated; the subject is precisely the site of such reiteration" [Butler, 1997: 16]. However, the subject being situated in the power relations of that very discourse has agency to trouble or subvert the norms through deviated performances.

Veiling as a gender performance, reminds us of drag metaphor used by Butler to concern the performances, which produce one's viable gender identity. Iranian Women to gain a viable identity of proper women have been under various dressing code. Here, we explore the dialectic relationship between women's veiling and dominant discourses of three historical eras in Iran.

\section{Iranian women's veiling during Pre-constitutional Era}

Traditionally, protection of wives, daughters and sisters meant the protection of a man's honor, reputation and his property. To secure the borders of their property from the menace encroachment of strangers' eyes, they would seclude women within walls or assign them a portable wall of hijab. The word chador in Persian language refers both to a head-to toe cloak and tent. In the same way that a tent shelters in conditions when there is no house wall, women's chador plays the role protection outside the walls. All women uniformly appeared in a three-piece dress, including a "chador", "a facial veil", and loose trousers. 
The defensive walls ported by all women gave them a homogenized identity of packed body, silenced mouth, and sealed mind. This performance of dressing norm was more than an imposed dressing style; rather, an identification of the second sex who was rejected individualism, self-representation, education, and controlled weak passive bodies, walled away from society. The performance of veil assured the prolonged domineering patriarchal discourse.

Women as the product of a traditional and religious discourse had internalized that veiling and seclusion would promise them the intelligible identity of a proper woman. In Giddens' words, women being deprived from resources such as knowledge, failed to consider the construction of their identities reflexively. He writes, "In such cultures things stayed more or less the same from generation to generation, $<\ldots$ and $>$ the changed identity was clearly staked out" [Giddens, 1991: 33]. For ages, harsh patriarchal convictions curtailed women's mobility, secluded and denied them education to perpetuate its authority.

\section{Iranian women's veiling during Post-constitutional Era}

Modification of Iranian women's dressing code concurs with the rise of constitutionalism in the beginning of $20^{\text {th }}$ century when Iran encountered Western modernization. Impressed by progress of Western countries, Iranian state and elites equalized progress with westernization. Embracing Western culture as a sign of modernization seemed to be the most effortless and overnight means of modernizing the face of country. European women's dressing style, which was conspicuously different from Iranian women's traditionally coded veil, sounded the most eye-catching sign of progress for state and elites. Women's veil and men's native attire as the sign of backwardness had to be eroded and replaced by western dressing style. "In 1936, at a graduation ceremony at the Women's Teachers' Training College in Tehran, Shah Pahlavi I announced unveiling". The state and elites defined the intelligible subjectivity in western style dressing. Women to be identified as modernized would transform their visible identity according to the norms. Female sex as a site to exercise power of competing discourse turned to be the bearer of the country's political and cultural emblems. The politicized veil produced a gap between two female subjectivity. While the packed female body signified traditional discourse, the unpacked one signified the opposing modernization, which regarded tradition as an impeding hamper on way of civilization.

The state claiming unveiling decree as a way to emancipate women from traditions imposed mandatory unveiling and took strict measures against veiling. Police would stop and attack veiled woman in stinging disdain tearing her veil as the obstacle of civilization. Except a few educated women with abroad experience [Sedghi, 2007: 88] most women believed lifting veil equalized with nakedness, sin and disgrace. Veiling had been "a sign of propriety and a means of protection against the menacing eyes of male strangers" [Beck, Nashat, 2004: 22]. Veil, as a base of their gender and religious identity, if resigned, implied identity alienation. The imposed veiling rather than being an emancipation caused more seclusion [Sedghi, 2007: 88], for most women who could not leave house without hijab. Limited number of women in western style dresses [Nashat, 1983: 27] suggested that a discourse to gain acceptability entails the subjects reiterate the norm.

Iranian women had been reiterating the norm of veiling for ages. The repetitions as covers over the regulatory forces of discourse naturalize the discursively constructed norms. Moreover, they assured religious authority the survival of the discourse that had produced that very action. Educated women or women with abroad experience to be identified as modern subjects, enterprised performing the norms of modernized discourse, not only in dressing mode but also in education and social activities, which were allocated only for unveiled women. The produced gap was more than a visible identity; rather it involved a clear breach between two mentalities, and two cultural identities of the same nation, who were obsessed with the question of to veil or not to veil.

The revolutionary uprisings bridged this gap when both unveiled and veiled women joined the revolutionary actions. "The mass demonstrations of 1978 marked the first 
time that women from different strata of society extensively joined the protest" [Ghorashi, 2004: 106-119]. Sullivan argues, "The chador, forbidden by Reza Shah $\langle\ldots$,. , associated with the backward and downtrodden during the Pahlavi era, was later used as an emblem of revolutionary protest by women of all castes and classes who marched against the Pahlavi regime" [Sullivane, 2000: 235-264]. Veil no more signified traditional and religious identity; rather it was a medium of social communication. "It represented strong political and ideological connotations that challenge class privilege, sexual license, corruption, and above all rejection of Western domination" [Milani, 2011: 153]. Some unveiled women, such as a European-educated poet, Tahere Saffarzade deliberately veiled to voice their protest by the veil. The politicized veil was no more a retrogressive, but a progressive sign expressing nationalism and anti-westernization. "The revolutionary culture became an umbrella under which various political ideologies and groups led their struggle against the regime" [Moallem, 2005: 84].

\section{Iranian women's veiling during Post-revolutionary Era}

The post-revolutionary Islamic discourse revived the gap between traditional and modern women when re-imposed veiling in 1983, by decree of mandatory veiling for all women even the foreigner tourists. However, chador was not the only one restricted choice of the new mandatory hijab. "Women could choose any attire they like so long as it covers them properly" [Bucar, 2012: 61]. Those women who were not in hijab preferred the new dressing style to traditional chador. The new dressing fashion included long and loose dark color dress, loose pants, long scarf, and black flat shoes. Women's veiling as the most representative symbol of Islamic Iran, was policed, monitored, and at the same time, internalized at different institutions. The gender-segregated schools and head-covering uniforms for girls initiated the promulgation of the ideal of hijab. The motto of "woman in hijab is like a gem in the shell" valorized a veiled female body. The school curriculum included Holly Quran and Islamic education as essential subjects. The contents and images of the books devoted ample attention to the ideals of hijab and gender segregation as well as heteronormative ideals. Women's voice was also veiled believing in "decorous tone of voice, and avoidance of singing, boisterous laughter, and generally any emotional outburst in public" [Khosravi, 2009: 45-47] to maintain the ideal of modesty. Just as the Shah used physical force to implement his compulsory unveiling policies in 1930s, Iranian government employed an especial morality police (referred to as Komitte) to enforce compulsory veiling [Amer, 2017: 58].

Politicized veil representing Islamic ideologies of the state gave intelligible subjectivity to women who performed it. The others would be jailed or would migrate to a place where they could have acceptable subjectivity as unveiled woman. The performance of veiling, as the idealized norm of the dominant discourse, contributed to stabilize the legitimacy of the state. Any resistance to mandatory hijab was regarded as a threat to Islamic norms and was condemned to suppression. "On March $8,1979,1000$ s of Iranian women marched in the streets to protest the compulsory wearing of Hijab"; however, they were confronted and failed [Elmesky, Yeakey, Marcucci, 2017: 375].

The construction of ideal female identity by Pahlavi regime was deconstructed by Islamic centrality of Ayatollah Khomeini's religious discourse. Both discourses highlighted women's emancipation, modesty and social involvement. Islamic discourse conceptualized unveiling not as emancipation but as enslavement. Women's emancipation was defined as emancipation from ignorance, inspiring women toward being educated. Unveiled woman's social involvement was viewed as objectification of women, who in made-up bodies would please men's desire. Pahlavi's motto of modesty and purity was recognized as absurd illusions driving women to impurity. The ideals of emancipation, purity and social involvement still survived yet they were followed by veiled women.

The dominance of Islamic discourse in the country geared up the social presence of veiled women, who by then were secluded indoors, either as passive sex during pre-constitutionalism or as abjects during the secularization of Pahlavi. The Islamic structure guaranteeing 
the protection of women left no excuse for fathers to send girls to schools. Besides, the clerical authorities who were more than religious preachers, got involved in women's social status. Ayatollah Khomeini in various speeches underlined women's social participation. Addressing women, he clarifies, "Women must participate shaping their own destiny [...]. Islam requires women contribute in all problems as men do. Women must participate in fundamental state matters" [Khomeini, 2001: 300-301].

The evolving female identity though in veils, were different from the traditional woman. Education generously equipped most women with awareness. The rising consciousness among women would cause new identities. Ansari assesses, "The expansion of women's education in post-revolutionary Iran identified as an unintended consequence of the revolution has been empowering women against the IRI's misogynistic ideology". While the Islamic discourse of the state generally desired the sustainability of traditional female identity, educated woman was hardly an ignorant submissive subject; instead, she reflexively considered and reconstructed her identity. "A girl who is attending college is less inclined to dumbly obey the instructions of her father" [Ebadi, Moaveni, 2006: 106].

Giddens acknowledges that while in traditional structures identity was fixed and handed by family, religion, gender, class, or any other sociocultural elements, in post traditional structures identity does not preexist as fixed to the conventions; instead, it is shaped and reshaped. He states, "Even the small choices we make in our daily lives-what we wear, are part of ongoing process of creating and recreating our self-identity. $<\ldots>$ Such choices are decisions not only about how to act but who to be" [ Giddens, 1991: 81]. Reflexive identity fashioning showed up in early changes women made in their dressing style. Women as active agents participated in construction of new identity in new veiling style. Their gradual amendments of color and style of outfits introduced the deviated performance paving the way for an imminent transformation of norms of dressing code.

Moreover, women started to receive information from sources other than national media or educational curriculum, which were overwhelmed by religious teachings mainly the prominence of veiling. The global Homogenization of cultures gradually permeated the geographical borders with the advent of satellite TVs and internet. Globalization, according to Giddens, is "interconnection [of societies and cultures] with one another, waves of social transformation crash across virtually whole of the earth's surface" [Appelrouth. Edles, 2010: 541].

Iranian women being exposed to boundless information about different cultures were inspired reflexivity about imposed veiling. However, considering the mandatory rule of hijab, women have fashioned a new fashion of hijab termed as "bad hijab" or "fashion hijab". Fashion hijab is a deviated performance of original intended hijab. "Although hijab law remains the same today, women have steadily and relentlessly pushed back the boundaries of the dress code. <...> They resist the demands by the hardliners to correct their hijab" [Honarbin-Holliday, 2013: 54]. Fashion hijab is not fundamentally different from the dressing code of Reza Shah's unveiling decree. Both are "adoption of a western style coat and a partial covering of the head, showing more hair, neck and body shape" [Cronin, 2003: 168]. While in 1930s, the state imposed this dressing code, today women as active agents have chosen it as a deviated citation of the standard imposed norm.

Islamic discourse constructs identities of women as its subjects, albeit, women being the subjects within these relations of power can enjoy agency to "articulate [their] opposition". The performance of norms enables the subject to resist. To be viable subject, they perform hijab. This can be assessed as "acquisition of being through citing of power". While their recitation of norms guarantees the sustainability of Islamic discourse, their deviated performances assure production of another discourse. According to Butler, it is "theatrical" recitation, or "rearticulatory practice", that enables the subject to resist the power [Butler, 2011: 15]. The widespread bad hijab in Iran is clothing revolution, an epitome of the contemporary form of resistance in Iran [Tehreem Junaid, 2015]. Fashion hijab, as a new recitation of veiling troubles Islamic discourse. In words 
of Butler, the subject "takes up or cites that very term as the discursive basis for an opposition" [Butler, 2011: 232].

The evolved Iranian female identity is the product of Islamic and western discourse. Her fashion hijab as the common product of these discourses is a colorful weapon against the Islamic ideologies. This veiling evolution is called as "clothing revolution of Iran, non-verbal form of protest, the epitome of the contemporary form of resistance in Iran; if you cannot uncover, why not cover "badly" [Asghar, 2015]. Shirazi writes, "every day the Iranian women protest the compulsory hijab decrees with small but visible defiance, wearing their hijabs too low or wearing a small hijab barely covering their head" [Shirazi, 2019].

Some women have launched to subvert the veiling norm and defy the legislation of mandatory hijab. A media campaign run on Facebook page of Masih Alinejad, an Iranian journalist in diaspora, posting her unveiled photos in Iran to challenge the law. The page called stealthy freedom inspired lots of women to share their unveiled photos in Iran. Some women also dare to challenge beyond virtual spaces, in crowded streets of Tehran, risking the arrest. They stand unveiled in the middle of a crowd holding their scarves. The scarf, hanging from a stick like a flag, voices a silent protest against compulsory hijab. However, the state immediately suppressed the uprising resistance.

Deviated performances of subject pressurize the authorities of Islamic State who mostly resist against cultural globalization. Unlike state's de-globalization efforts, western culture "is gradually seeping into bones of Iranian society" ${ }^{1}$. Based on the most recent news, 94 percent of Iranians have access to internet ${ }^{2}$ and 81percent watch satellite $\mathrm{TVs}^{3}$. Receiving 380 channels of dance and music as well as 80 channels, Iranian women are exposed to Western dressing style [Bicharanlu, 2016]. Abundance of Iranian quantitative researches prove the direct association of "miss-veiling" and satellite TVs [Khodadadi, Ahmadi, 2016].

The modern identity constructed under the influence of Western culture is opposed to what Islamic state expects the subject perform as ideal subjects. "As this alternative media grows, it makes U.S. sources of soft power easier for Iranian audiences to absorb and threatens to divert them from regime programming" 4 . Western media representing Western woman's liberty of choice, pictures an aggressive image of Islamic Iran depriving women from their natural right of dressings choice in contrast to Western democracy and gender equality [Basiri, 2012]. Addressing mandatory veiling as an evident deny of liberty and oppression of women, they target women's minds and hearts. "The veil has become an easy visual equivalence for cultural backwardness, a form of shorthand to represent Europe's enlightened cultural standing" [Jones, 2011: 137].

Women's deviation from the idealized hijab mirrors Western cultural invasion. While the imposed Iraq war threatened the geographical borders, today Islamic culture and ideology is aimed at by those opposing the state. During the Iran-Iraq war, initiated early after Islamic Revolution, when women's Islamic ideologies remained intact. While men were fighting at the fronts, women were vigilant to voice their support of Islamic state by their veils. A common dictum declared, "women's veil is more powerful than martyreds' blood". However, cultural invasion is more formidable than hard-war. Islamic discourse insists at internalizing hijab and producing veiled subjects who in their Islamic performances support the protraction of Islamic discourse. Celebration of Western democracy can be a regarded as soft

\footnotetext{
Sabet F., Safshekan R. Soft War: A New Episode in the Old Conflicts Between Iran and the United States // Iran Media Program. — 2013. — URL: http://repository.upenn.edu/iranmediaprogram/9 (accessed 30.01.2021).

2 The latest statistics on Internet penetration in Iran // Mehr news agency. - 2020. - 4 aug. — URL: https://www.mehrnews. com/amp/4990207/ (accessed 30.01.2021).

3 IRIBResearghCenter:How muchIraniansWatchSatelliteTVs?.//Donya-eEqtesadPress._2019._5oct._URL:https://donyae-eqtesad.com/\%D8\%A8\%D8\%AE\%D8\%B4-\%D8\%B3\%D8\%A7\%DB\%8C\%D8\%AA-\%D8\%AE\%D9\%88\%D8\%A7\%D9\%8662/3579552-\%DA\%86\%D9\%86\%D8\%AF-\%D8\%AF\%D8\%B1\%D8\%B ５\%D8\%AF-\%D9\%85\%D8\%B1\%D8\%AF\%D9\%85\%D8\%AA\%D9\%85\%D8\%A7\%D8\%B4\%D8\%A7\%D A\%AF\%D8\%B1-\%D9\%85\%D8\%A7\%D9\%87\%D9\%88\%D8\%A7\%D8\%B 1\%D9\%87-\%D9\%87\%D8\%B3\%D8 \%AA\%D9\%86\%D8\%AF (accessed 30.01.2021).

4 Sabet F., Safshekan R.
} 
power against the Islamic discourse. According to Joseph Nye, "Seduction is always npmore effective than coercion, and many values like democracy, human rights, and individual opportunities are deeply seductive" [Nye, 2004: X]. Iranian states views western soft power as soft war threatening the country's social and cultural security. Iranian supreme leader warning against soft war states, "West continues soft war against Iran... The enemies want to weaken the system from inside" ${ }^{\prime \prime}$. Today western societies do not need to recruit Reza Shah who violently unveiled women, globalized media gently and silently persuades that to be identified as a modern woman, and to enjoy liberty, women need to subvert the traditional ideal of veiling. Awakened women, performing fashion hijab, deviate the imposed norm to prove their agency that threatens the Islamic discourse, which depends on recitation of its standard hijab by the subjects. Fashion hijab reflects initiation of a new discourse that resists against the traditional style of veiling. Resistance against the idealizations of the dominant Islamic discourse has the potential of subverting the norms of that discourse. Fashion hijab as a new norm threatens the norms defined by Islamic discourse of the state.

The competition between traditional and modern discourses is reflected in the wide gap between women in fashion hijab, and women in traditional veiling. While both are active in different social arenas, the first group in fashion hijab is identified as modernized; the second in traditional veiling is identified as religious. The recitation of traditional veiling promises maintenance of Islamic discourse defined by the state, whereas the deviated new version threatens its sustainability.

\section{Conclusion}

The research studied Iranian women's veiling as a gender performance of Iranian women since pre-constitutional era to the current age. It is manifested that in each three different eras the competing discourses attempted to define women's dressing code, which has been the most visible epitome of that discourse. The performance of especial dressing code in Iran has been associated with women's identification with that discourse. Women's politicized veil signified their identity in accordance with the discourse they want to be identified. Women were imposed the veil, then unveiled, and again re-imposed the veil by religious or secularized discourses. However, they have not been just the receiver of imposed norms. The discourses to gain sustainability needed recitation of norms by the subjects. The recitation of performances of norms gives subjects the agency to subvert the norms.

Today Iranian women equipped with education and under the influence of global media is awakened performing a deviation of hijab as fashion hijab, which is regarded as a threat against Islamic Iran.

It is concluded that there has been a dialectical relationship between veiling performance of subjects as agents and viability of the dominant discourse. The failure of imposed unveiling or veiling proves the significance of reiteration of norms by subjects to give life to imposed norms. It is confirmed that the veiling performances that deviate from the original norm will produce a new norm. Deviated recitation is a threat to the standard ideal that can be subverted gradually. Moreover, hijab as special dressing style imposed on women easily naturalizes sexual differences, which provides the centrality of heteronormativity to hold the tie between hijab as the signifier signifying women. The centrality of heteronormativity as opposed to homosexuality is obviously significant in Islamic societies.

For future studies, it is recommended to investigate the Megatrend of mandatory hijab and potential veiling uprisings in Iran.

\footnotetext{
5 Hafezi P. Iran's Khamenei calls for vigilance against West's 'soft war': state TV // REUTERS. — 2016. - 26 may. - URL: https://www.reuters.com/article/us-iran-west-vigilance-idUSKCNOYH10P (accessed 21.01.2021).
} 


\section{Список литературы:}

Butler J.P. Bodies that Matter : on the Discursive Limits of "Sex." — New York ; London : Routledge, 2011. $\mathrm{XXX},-219 \mathrm{p}$.

Butler J.P. The Psychic Life of Power : Theories in Subjection. - Stanford, CA : Stanford University Press, 1997. - $218 \mathrm{p}$.

Giddens A. Modernity and Self-identity : Self and Society in the Late Modern Age. — Stanford, Calif. : Stanford Univ. Press, 1991. - 256 p.

Sedghi H. Women and Politics in Iran : Veiling, Unveiling, and Reveiling. —Cambridge : Cambridge University Press, 2007. - XVI, 341 p.

Beck L. Women in Iran from 1800 to the Islamic Republic / L. Beck, G. Nashat — Urbana : University of Illinois Press, 2004. - XIII, 288 p.

Nashat G. Women and Revolution in Iran. — Boulder: Westview Press, 1983. — IX, 301 p.

Ghorashi H. Identities and the Sense of Belonging: Iranian Women Activists in Exile // Refugees and the Transformation of Societies : Agency, Policies, Ethics and Politics / ed. F. Essed, G. Freeks, J. Schrijvers - New York; Oxford : Berghahn Books, 2004. - P. 106-121.

Sullivane Z. Eluding the Feminist, Overthrowing the Modern? Transformations in Twentieth-Century Iran // Global feminisms since 1945 / ed. Smith B.G. — London; New York : Routledge, 2000. - P. 235-264.

Milani F. Words not Swords : Iranian Women Writers and the Freedom of Movement. - New York: Syracuse University Press, 2011. - XXIV, 345 p.

Moallem M. Between Warrior Brother and Veiled Sister : Islamic Fundamentalism and the Politics of Patriarchy in Iran. — Berkeley : University of California Press, 2005. — IX, 269 p.

Bucar E.M. Islamic Veil — a Beginners Guide. — Oxford : Oneworld, 2012. — 224 p.

Khosravi S. Young and Defiant in Tehran. - Philadelphia, Pa. ; Oxford : University of Pennsylvania Press, 2009. $-224 \mathrm{p}$.

Amer S. What is Veiling? - Chapel Hill : University of North Carolina Press, 2017. - XII, 234 p.

Elmesky R. The Power of Resistance : Culture, Ideology and Social Reproduction in Global Contexts / R. Elmesky, C.C. Yeakey, O. Marcucci. — Bingley, UK : Emerald Publishing, 2017. —XX, 487 p.

Khomeini I.R. Sahifeh-e Nur. Vol. 6. — Published by Tab-o-Nashr, 2001. - 324 p. (In Persian)

Ebadi S. Iran Awakening : a Memoir of Revolution and Hope / S. Ebadi, A. Moaveni - New York: Random House, 2006. - XVI, $232 \mathrm{p}$.

Appelrouth S. Sociological Theory in the Contemporary Era: Text and Readings / S. Appelrouth, L.D. Edles. - Thousand Oaks, Calif. ; London : Pine Forge Press, 2010. - 676 p.

Honarbin-Holliday M. Becoming Visible in Iran : Women in Contemporary Iranian Society. — London ; New York: I.B. Tauris, 2013. - XII, 205 p.

Cronin S. The Making of Modern Iran : State and Society under Riza Shah, 1921-1941. — London; New York : Routledge, 2003. - 312 p.

Asghar T.J. Good Hijabi, Bad Hijabi: The Politics of Women's Clothing in Iran // Journal of Georgetown University-Qatar Middle Eastern Studies Student Association. — 2015. — Vol. 2015, №1. — 10 p. — DOI: 10.5339/messa.2015.10.

Shirazi. The Veiling Issue in 20th Century Iran in Fashion and Society, Religion, and Government // Religions. — 2019. — Vol. 10, № 8. - P. 461. — DOI: 10.3390/rel10080461.

Bicharanlu A. Main Ways of Absorbing Audience in Three Satellite TV Channels // Motaleat-e resanehaye novin. - 2016. - № 33. - P. 57-90. (In Persian)

Khodadadi J. The Role of Cultural Elements and Media in Women's Hijab / J. Khodadadi, K. Ahmadi // Zanan va Khanevade. — 2016. — № 33. - P. 7-22. (In Persian)

Basiri M. Soft War Against Iran // Motaleat e Godrat e Narm. — 2012. — № 5. - P. 151-177. (In Persian)

Jones R.B. Postcolonial Representations of Women : Critical Issues for Education. — Dordrecht : Springer, 2011. - VIII, 234 p.

Nye J.S. Soft Power : the Means to Success in World Politics. — New York: Public Affairs, 2004. - XVI, $191 \mathrm{p}$. 


\section{References:}

Butler, J. P. (2011) Bodies that Matter : on the Discursive Limits of 'Sex'. New York; London: Routledge. Press.

Butler, J. P. (1997) The Psychic Life of Power: Theories in Subjection. Stanford, CA: Stanford University

Giddens, A. (1991) Modernity and Self-identity : Self and Society in the Late Modern Age. Stanford, Calif.: Stanford Univ. Press.

Sedghi, H. (2007) Women and Politics in Iran : Veiling, Unveiling, and Reveiling. Cambridge: Cambridge University Press.

Beck, L. and Nashat, G. (2004) Women in Iran from 1800 to the Islamic Republic. Urbana: University of Illinois Press.

Nashat, G. (1983) Women and Revolution in Iran. Boulder: Westview Press.

Ghorashi, H. (2004) 'Identities and the Sense of Belonging: Iranian Women Activists in Exile', in Essed, F., Freeks, G., and Schrijvers, J. (eds) Refugees And The Transformation Of Societies : Agency, Policies, Ethics and Politics. New York ; Oxford: Berghahn Books, pp. 106-121.

Sullivane, Z. (2000) 'Eluding the Feminist, Overthrowing the Modern? Transformations in TwentiethCentury Iran', in Smith, B. G. (ed.) Global feminisms since 1945. London ; New York: Routledge, pp. 235-264.

Milani, F. (2011) Words not Swords : Iranian Women Writers and the Freedom of Movement. New York: Syracuse University Press.

Moallem, M. (2005) Between Warrior Brother and Veiled Sister : Islamic Fundamentalism and the Politics of Patriarchy in Iran. Berkeley: University of California Press.

Bucar, E. M. (2012) Islamic Veil - a Beginners Guide. Oxford: Oneworld.

Khosravi, S. (2009) Young and Defiant in Tehran. Philadelphia, Pa.; Oxford: University of Pennsylvania Press.

Amer, S. (2017) What is Veiling? Chapel Hill: University of North Carolina Press.

Elmesky, R., Yeakey, C. C. and Marcucci, O. (2017) The Power of Resistance : Culture, Ideology and Social Reproduction in Global Contexts. Bingley, UK: Emerald Publishing.

Khomeini, I. R. (2001) Sahifeh-e Nur. Vol. 6. Published by Tab-o-Nashr. (In Persian)

Ebadi, S. and Moaveni, A. (2006) 'Iran Awakening : a Memoir of Revolution and Hope'. New York: Random House.

Appelrouth, S. and Edles, L. D. (2010) Sociological Theory in the Contemporary Era: Text and Readings. Thousand Oaks, Calif. ; London: Pine Forge Press.

Honarbin-Holliday, M. (2013) Becoming Visible in Iran : Women in Contemporary Iranian Society. London; New York: I.B. Tauris.

Cronin, S. (2003) The Making of Modern Iran : State and Society under Riza Shah, 1921-1941. London ; New York: Routledge.

Asghar, T. J. (2015) 'Good Hijabi, Bad Hijabi: The Politics of Women's Clothing in Iran', Journal of Georgetown University-Qatar Middle Eastern Studies Student Association, 2015, p. 10. doi: 10.5339/ messa.2015.10.

Shirazi (2019) 'The Veiling Issue in 20th Century Iran in Fashion and Society, Religion, and Government', Religions, 10(8), p. 461. doi: 10.3390/rel10080461.

Bicharanlu, A. (2016) 'Main Ways of Absorbing Audience in Three Satellite TV Channels', Motaleat-e resanehaye novin, (33), pp. 57-90. (In Persian)

Khodadadi, J. and Ahmadi, K. (2016) 'The Role of Cultural Elements and Media in Women's Hijab', Zanan va Khanevade, (33), pp. 7-22. (In Persian)

Basiri, M. (2012) 'Soft War Against Iran', Motaleat e Godrat e Narm, (5), pp. 151-177. (In Persian)

Jones, R. B. (2011) Postcolonial Representations of Women : Critical Issues for Education. Dordrecht: Springer.

Nye, J. S. (2004) Soft Power : the Means to Success in World Politics. New York: Public Affairs. 


\section{Information about the author}

Leila Khadem Makhsuos Hosseini — PhD (Cultural Studies), independent researcher (Iran)

Conflicts of interest. The author declares absence of conflicts of interest.

\section{Информация 06 авторе}

Лейла Хадэм Максус Хоссейни — кандидат культурологии, независимый исследователь (Иран) Конфликт интересов. Автор заявляет об отсутствии конфликта интересов.

The article was submitted 11.02.2020; approved after reviewing 10.03.2021; accepted for publication 12.03.2021.

Статья поступила в редакцию 11.02.2020; одобрена после рецензирования 10.03 .2021 ; принята к публикации 12.03.2021. 